\title{
FACTORS OF POSSIBLE RISK PREDICTION FOR FINANCIAL STATEMENT FALSIFICATION IN BANKING SECTOR OF RUSSIAN FEDERATION
}

\author{
Genrietta Soboleva \\ St. Petersburg State University \\ Sofya Soboleva \\ St. Petersburg State University of Economics \\ Dina Lvova \\ St. Petersburg State University
}

\begin{abstract}
It is known that the financial statements are the subject of falsification. Risk assessment of possible falsification is a complex and urgent problem, which concerns a large number of scientific studies that use in modeling a variety of information contained in the financial statements. This paper presents the results of a study of the Russian companies financial reports falsifications. As a special object of a study are chosen commercial banks, whose licenses were revoked by the Bank of Russia in 2013-2016 year. The study is based on the hypothesis that formalized "red flags" are required to determine the risk of fraud by various characteristics of the company's activities. The presence of significant evidence obtained earlier, prompted to choose a composition of the Board of Directors as area of research for highlighting "red flags". Paper examines the connection between the risk of distortion of the financial statements and the company's Board of Directors. Based on empirical analysis of groups of banks implicated in the falsification of financial statements, this study discusses the characteristics of the Board of Directors that can be identified as important to assess the possible risk of fraud.
\end{abstract}

Keywords: audit, fraud indicators, risk assessment fraudulent

JEL code: M410, M420

Corporate fraud deals sufficient damage both to companies and to the world community. Fraudulent actions are usually divided into three types: active misappropriation, corruption and statement falsification. The statistics, which was the result of ACFE research, shows that the falsification of financial statement is the most harmful for companies type of fraudulent actions.

That is the reason why society is interested in timely detection of fraudulent actions towards the falsification of the financial statement. In particular, such function bears Russian community of auditors.

Russian audit standards have already demanded from auditors to fulfill the actions aimed to detect possible fraudulent actions. Nowadays Russian Federation makes a transit to International Audit Standards (IAS). The analysis of practice of Russian transit to International Financial Reporting Standards (IFRS) showed the improvement of quality and transparency of financial statement (Generalova, Soboleva, 2014). The fact that Russian auditors will have to fully consider the demands of IAS about higher assessment of risk of not detecting material misstatement, which appears as a result of fraud, must help to improve the quality of audit. It should be noted that international standards not only impose stricter requirements to the actions of auditors aimed to detect and assess the risk, but also give detail recommendations for auditors. Appendix 1 of Standard 240 "The auditor's Responsibilities Relating to Fraud in an Audit of Financial Statements" provides a list of factors considered as indicators of possible fraudulent actions. 
Modern Russian practice shows that actions of auditors aimed to detect the facts of financial statement falsification are ineffective. In years 2013-2016 the Central Bank of Russian Federation has revoked about 400 licenses from Russian banks. More than half of them had the fact of the falsification of the financial statement as a reason of revoking the license, but these circumstances were not reflected in the audit reports.

Unfortunately, in Russian tradition of accounting activity, which tends to formalization, even the provisions of Standard 240 can affect the actions not enough to make them effective. It is possible that the accounting tradition still continues to operate when only strict and detailed legislation encourages accounting employees to actions.

This can also be seen on historical examples: in particular, in 1895 the "Novoye Vremya" (New time) newspaper encouraged its readers to fight the new evil. Earlier, claimed the newspaper, the accounting reports were compiled with an optimistic goal to hide the actual situation from the shareholders. With the establishment of a percentage levy on profits "all accounting ingenuity went to the pessimistic goal of concealing the true state of affairs from the fiscal authorities" (Shhetinin-Kakuev, 1895, p. 162). As can be seen, in both cases financial statement was falsified.

The accountants of commercial and industrial enterprises and banks, the payers of interest charges, worked hard to invent more and more ways to hide the true situation in their reports. In 1913 A.A. Chastukhin published "Summary of practices by trade books", the manual for taxpaying inspectors of Moscow with the analysis of typical ways of statement distorting. But at the beginning of the twentieth century distortions in accounting reached enormous proportions. And as the method of fighting was chosen the reforming of legislation about joint stock companies and trade books. In this way, even before the revolution in Russian economics one of the most important factors for struggling with falsification was legislative control and direct intervention of the regulator into the process of assessing the risk of falsification. In the Soviet period of development acted fundamentally different model of functioning economics and banking sector, fraudulent actions were of a different nature. At the same time formalist state principles and methods of regulation reached their absolute level of development. The changes in socio-economic model of society in Russia in year 1991 led to complete restructuring of existed mechanisms. In particular, began to form completely new banking sector, which did not exist in USSR. The process of its formation took a long time. During first 10-15 years banks acted in semi-illegal sphere and the process of their regulation was still developing. Only in the beginning of $21^{\text {st }}$ century it became possible to talk about realization of active politics, aimed to make Russian banking model act in the same legislative field as the banking system of developed countries. Since 2003 began the reform to improve bank supervision and financial statement by IFRS implementation. Was implemented the system of information about real owners' disclosure. The legislation made stricter the requirements to the officials and their business reputation. In 2004 were worked out and implemented the requirements of mandatory standards and order reservation co-existing with national standards and practices. In 2007 was established the EU-Russia dialogue on financial and macro-economic policies, and implementation of its activities is carried out within the "roadmap" for the formation of a common economic space. At the moment Russia is member of Basel Committee on Banking Supervision and fully implements all the requirements of Basel agreements. Thus, nowadays accounting and legal rules in banking system are completely agree with those acting in developed countries. This allows us to use western models for assessing the activities of banking sector and detecting risks of falsification of financial statements.

A significant number of researches was spent aimed to determine both conditions for fraudulent actions and reasons of them happening. Many researches, focused on detecting conditions and 
factors assisting to the fraudulent actions, found a connection between quality of management, state of the control environment and risk of fraud. Researches of Dechow proved that weak corporate management is connected with higher possibility of fraud. They have come to a conclusion that companies, which are manipulating their income, with higher probability will have less independent Board of directors with general director as a chairman. (Dechow, 1996) Afterwards quality of management was also evaluated as very important factor to raise the risk of falsification. Was detected a high level of connection between quality of management and falsification of financial statement (Bell and Carcello, 2000). Hernandez and Groot also determined ethic factors linked to the management as important factor for assessing risk of fraud. (Hernandez and Groot, 2007)

Results of these and other numerous researches became the reason why we focused our attention on management system of Russian banks to assess possible factors which can be considered as the indicators of fraudulent actions.

As the object of research we have chosen the board of directors of the company. The aim of the research was to distinguish as much formalized "red flags" for risks assessment, based on characteristics of activity of the company, as possible. As the object of research we have chosen the board of directors of the company. One of the most known researches of the connection between the board of directors and the risk of company falsifying its financial statement was done by Mark Beasley. This research has established the connection between the share of independent directors in the board and the risk of falsifying the statement (Beasley, 1996). He discovered that the board of directors in companies found guilty of falsifying their financial statement had lower percent of external members than in boards of conscientious companies.

This research had marked the beginning of the study detecting the links between the structure of board of directors and fraudulent actions. In the work of D. Farber was discovered that companies found guilty of falsifying their financial statement had smaller number of external numbers in their board of directors and their smaller percentage, as well as fewer meetings of the Audit Committee. (Farber, 2005)

The research of Efendi, in which were analyzed different banks, distinguished general director being the chairman of Board of directors as one of the most important risk factors of falsification of financial statement. (Efendi, 2007)

Important role of Board of directors and independence of its members are staying equally important for countries with different levels of economic development. The research, made in Australia in years 1998-2000, allowed to determine the connection between the share of independent directors in the Board and possibility of falsification of financial statement. (Sharma, 2004) The researches, based on data of companies from 12 different jurisdictions with different legal conditions. The aim of research was to detect the possibility of ethic norms of company being influenced by the Board of directors. The results of the research allowed the author to claim that the presence of independent directors establishes stricter ethic norms in the company. (García-Sánchez, 2015)

One more research based on data of American banks was also considering the problem of connection between board of directors and risk of falsifying the statement; it also showed that the structure of board of directors has sufficient influence on combating illegal actions of US banks (Nguyen, 2016). The same type of research done by J. S. Ang (J. S. Ang et. al., 2016) and based on data of 262 Chinese companies trading in USA also showed that companies prone to fraud have smaller percentage of independent directors in their board. Similar research, concerning banking organizations, was based on data from Canada (Cormier, 2016). 
The presence of significant evidence found by researchers encouraged us to choose the board of directors as an object of detecting the "red flags". The presence of significant proofs, received by researches, encouraged us to choose as object of research for detecting the "red flags" the presence of independent members in Board of directors. The research was based on records of financial statements of banks found guilty of fraudulent actions in 2014. Financial statements of selected credit institutions were considered for year 2013. Also was considered the "standard" sample from bank reports for the same period of time. The standard sample included 20 organizations from bank ratings which are similar to the group of swindlers by value of their net assets. In the formation of the sample were excluded credit organizations with sufficient differences from other similar organizations. The sample was formed by random.

At first was carried out a statistic research of samples formed. In case of M. Beasley's hypothesis being wrong we should expect that data of the samples will not have statistically significant differences. The samples are not interdependent because data included into these samples characterize objects which are not linked to each other. The null hypothesis has been put forward about the equality of initial samples and the alternative hypothesis about presence of significant differences. The check on null hypothesis was performed by using the MannWhitney test. This criterion allowed us to make a comparison of two independent samples by the structure of Board of Directors. From two analyzed samples was formed unified ranked series; after that two samples were formed back but their data kept their rank numbers. For each sample was counted its sum of ranks and, based on the biggest sum of ranks and on number of elements in its sample, was calculated the value of Mann-Whitney criterion with the use of special formula. After application of chosen criterion, the resulting value of asymptotic significance index $(0,001)$ was less than the normative one. This shows that the calculated value of Mann-Whitney criteria is less than the tabled one or equal to it. This circumstance did not allow to accept the null hypothesis and lead us to the conclusion that in conditions of Russian economic board of directors and its structure can be considered as significant risk factors in determining probability of fraud risk, as in other countries. (Soboleva, 2016)

Confirmation of significance of the information about board of directors for detecting the risk of falsification of financial statement gave us the base for detailed descriptive and qualitative analysis. During the analysis main statistics indicators for the samples chosen, such as mean values, mode, median, dispersion and asymmetry, were calculated and given in the table below, graphical comparison of quantitative and structural characteristics for the samples studied and was done their qualitative analysis. As a quantitative characteristic was counted total number of members in board of directors, as a structural one - percentage of independent members in board of directors.

Table 1. Descriptive characteristics for control groups on quantitative and structural data

\begin{tabular}{|l|r|r|r|r|}
\cline { 2 - 5 } & \multicolumn{1}{c|}{$\begin{array}{c}\text { Statistical } \\
\text { characteristics of } \\
\text { analyzed indicator for } \\
\text { "standard" group on } \\
\text { quantitative data }\end{array}$} & $\begin{array}{c}\text { Statistical } \\
\text { characteristics of } \\
\text { analyzed indicator } \\
\text { for study group on } \\
\text { quantitative data }\end{array}$ & $\begin{array}{c}\text { Statistical } \\
\text { characteristics of } \\
\text { analyzed indicator } \\
\text { for "standard" } \\
\text { group on structural } \\
\text { data }\end{array}$ & $\begin{array}{c}\text { Statistical } \\
\text { characteristics of } \\
\text { analyzed } \\
\text { indicator for } \\
\text { study group on } \\
\text { structural data }\end{array}$ \\
\hline Mean $(\overline{\mathrm{Y}})$ & 7.925925926 & 6.6 & 0.740150179 & 0.477460317 \\
\hline Mode $(\mathrm{Mo})$ & 7 & 5 & 0.857142857 & 0.6 \\
\hline Median $(\mathrm{Me})$ & 7 & 7 & 0,777777778 & 0.571428571 \\
\hline Dispersion $\left(\sigma^{2}\right)$ & 4.225071225 & 3.828571429 & 0.014810849 & 0.072001026 \\
\hline Asymmetry $(\mathrm{As})$ & 0.623809329 & 0.586177246 & $-0,979773031$ & 0.164444864 \\
\hline
\end{tabular}


Statistical characteristics, which are given in Table 1, as a result of analysis show that banks found guilty of fraud have significant differences from banks of "standard" group compared to them. These descriptive characteristics confirm that the study group, unlike the standard one, has values of mean and mode less than the median, which means that the highest values of the population has a smaller numerical value. This conclusion is also confirmed by presence of leftsided asymmetry in the group of falsifiers. Similar data for the "standard" group show that the "standard" sample is closer to normal distribution, which means that this characteristic is influenced by specifics of bank activities and shows indicators reacting at its conditions and circumstances.

The results of analysis of board of directors' structure and percentage of independent members show that samples have different types of distributions, the "standard" group - right-sided, while the study group has left-sided distribution. The "standard" group has not only higher value of studied indicator, but also the whole sample has more observation units with higher value of indicator studied.

Then qualitative analysis of personal membership of board of directors was performed. Descriptive analysis is not possible because of absence of observable negative indicators in "standard" group of banks. Results of quantitative and qualitative analysis allowed to detect the "red flags" which can be considered as important indicators of high risk of falsified financial statements.

For banks found guilty of falsifications is typical minimal number of board of directors (their number is at the lowest limit allowed by law). Also fraudster banks tend to have minimal number of independent members in their board of directors and to include into membership people, whose professional knowledge obviously cannot meet the challenges decided by the bank organization.

The indicators of such professional dysfunction are: field of activity, scope of organizations where external members work, etc. Such indicators are typical for the group studied: it was present in $80 \%$ of banks. Fraudster banks also show strong affiliation of membership. In the membership of board of directors in number of banks are directly present affiliated between each other and dependent from the bank organization persons. In our opinion, selected indicators should be taken into account by auditors while assessing risks of financial statement being falsified.

\section{Concluding remarks}

In this way, the results of the research allowed us to confirm the existence of the link between the structure of Board of directors and risk of falsification of financial statement. These conclusions make it possible to suggest that the use of non-financial information from statement can be possible for preliminary analysis based on "red flags" for assessing possible risk of financial statement being falsified.

The data of descriptive analysis show that the indicators of possible falsification are:

- a small number of directors on the board, approaching to the minimum number established by law;

- the characteristic more difficult to formalize is the share of independent members of Board of directors, taken in combination with previous indicator. If this indicator does not exceed $60 \%$, then this is a zone of high risk. If this indicator is below $50 \%$, that it can be considered as a "red flag" by itself. 
Additional "red flags", detected during the research, are: position held does not testify to the presence of expertise in the financial sector or the interdependence exists between the members of the Board of Directors. Additional existence of these characteristics makes the risk of falsification even higher.

The use of detected "red flags" can be of a help to auditors in assessing risk of falsification of the statement.

\section{References}

Ang, J. S., Jiang, Z., Wu, C. (2016). Good Apples. Bad Apples: Sorting Among Chinese Companies Traded in the U.S. Journal of Business Ethics, vol. 134, no. 4, pp. 611-629.

Beasley, M. (1996). An Empirical Analysis of the Relation between the Board of Director Composition and Financial Statement Fraud. The Accounting Review, vol. 71, no. 4, pp. 443465 .

Bell, T. B., Carcello. J. V. (2000). A decision aid for assessing the likelihood of fraudulent financial reporting. Auditing: A Journal of Practice and Theory, vol. 19, no. 1, pp. 169-184.

Cormier, D., Lapointe-Antunes, P., Magnan, M. (2016). CEO power and CEO hubris: a prelude to financial misreporting? Management Decision, vol. 54, no. 2, pp. 522-554.

Dechow, P. M., R. G. Sloan, Sweeney A. P. (1996). Causes and consequences of earnings manipulation: An analysis of firm's subject to enforcement actions by the SEC. Contemporary Accounting Research, vol.13, spring, pp. 1-36.

Efendi, J., Srivastava A., Swanson E. (2007). Why do corporate managers misstate financial statements? The role of option compensation and other factors. Journal of Financial Economics, vol. 85 no. 3, pp. 667-708.

Farber, D. (2005). Restoring trust after fraud: Does corporate governance matter? Accounting Review, vol. 80, no. 2, pp. 539-561.

García-Sánchez, I. M., Frías Aceituno, J. V., Rodríguez Domínguez, L. (2015). The ethical commitment of independent directors in different contexts of investor protection. Business Research, vol. 18. no. 2, pp. 81-94.

Generalova, N., Soboleva, G., Sokolova, N. (2015). IFRS-Russian experience: Realities and challenges. Proceedings of the 25th International Business Information Management Association Conference - Innovation Vision 2020: From Regional Development Sustainability to Global Economic Growth, IBIMA 2015, pp. 601-608.

Hernandez, J. R., Groot. T. (2007). How trust underpins auditor fraud risk assessments. Working paper, Free University of Amsterdam, ARCA, Amsterdam Research Center in Accounting pp. 1-58.

Nguyen, D. D., Hagendorff, J., Eshraghi, A. (2016). Can Bank Boards Prevent Misconduct? Review of Finance, vol. 20, no. 1, pp. 1-36.

Report to the Nations on Occupational Fraud and Abuse: Global Fraud Study ACFE, 2014 (2014), available on-line at http://www.acfe.com/rttn/docs/2014-report- to-nations.pdf (04 Sep 2016).

Sharma, V. D. (2004). Board of director characteristics, institutional ownership, and fraud: Evidence from Australia. Auditing, vol. 23, no. 2, pp. 105-117

Soboleva, G. (2016). Analiz vzaimosviazi sostava soveta direktorov kompanii i riska fal\&\#39;sifikacii finansovoi otchetnosti [Analysis of the relationship between the composition 
of the Board of Directors of the company and the risk of fraud in financial reporting], Auditorskie Vedomosti, vol. 6. 57-65. (in Russian)

Shhetinin-Kakuev, K. G. (1895). K otchetnosti torgovo-promyshlennyh predpriyatii [To the reporting of commercial and industrial enterprises], Schetovodstvo, vol. 9, no.11-12. 162. (in Russian)

Yatim, P., Iskandar, T. M., Nga, E. (2016). Board attributes and foreign shareholdings in Malaysian listed firms. Journal of Management and Governance, vol. 20, no. 1, 147-178. 